As recruiting medical officer at Winchester, out of 530 recruits during the past year I have rejected 21 for varicocele and these were all large varicoceles, left-sided, and with the testicle hanging abnormally low. In my opinion if a recruit has a large varicocele his gymnasium course will cause it to pain him and I have seen these varicoceles become very painful and tender during a gymnastic course.

It was only quite recently that a recruit who had been passed in London was sent to this depôt. He had a large left-sided varicocele. The medical officer who passed him wrote on his medical-history sheet "that he was willing to undergo an operation if the varicocele in any way interfered with his duties." In less than ten days after joining this station this recruit reported sick, saying that he suffered so much pain in the left scrotum and groin that he wished to undergo an operation. This was granted. A few months ago a middle-aged man came to my out-patient department at the County Hospital with a large varicocele and varicose veins of both legs. The varicocele was leftsided and the testicle hung very low; he stated that the varicocele gave him more pain than the veins in his legs and the pain was chiefly at night after a day's work. He was a farm labourer, married, and with a large family. He refused operation and was given a suspensory bandage. In Mr. Watson Cheyne's "Manual of Surgical 'Treatment" appears: "Varicocele-Operative. When for any reason an operation is desired a complete cure can be effected by a very simple operation which has no risk if it be done aseptically."

In conclusion, I think that-1. Varicocele is an abnormal condition, leading in some cases to changes in the testicle and in some cases giving rise to definite symptoms, such as pain, tenderness, \&c., and although operation may nnt prevent the changes in the testicle it does relieve the symptows. 2. That in some cases the condition may be relieved by palliative treatment-viz., support, regulation of the bowels, cold douches, and regular exercise. 3. That operation may be advised if the varicocele is large and causes the testicle to hang very low and if the varicocele gives rise to symptoms which are not relieved by palliative treatment. 4 . That varicoceles ought not to cause rejections for the services but that candidates for the services suffering from varicocele should be asked to sign a form on passing into the service stating that they are willing to undergo an operation should the varicocele in any way interfere with their duties. I think this would prevent any tendency to malingering.

I am, Sirs, yours faithfully, HERBERT JAMES GODWIN, Surgeon to the Royal Hants County Hospital; late Civi
Surgeon, South African Field Force; Medical Officer

Oct. 2nd, 1905. in Charge of Recruits, Winchester.

\section{HOT-AIR VENTILATION.}

\section{To the Editors of THE LANCET.}

SIRs,-The most careless observer cannot but have noticed the increased, and daily increasing, interest displayed by the general public in the questions of health and longevity. 100 years ago, or less, when our forefathers awaited impatiently the retirement of the ladies as the signal for an orgy of excess, the term "hygiene" was scarcely recognised as a word to be used in ordinary converse. Now we talk glibly of " bacteria" and "microbes." As for our hospitals and gaols, in the matter of ventilation, it was little thought of in summer and regarded as something suggestive of insanity in winter. Tempora mutantur, nos et mutamur in Nowadays in our hospitals and prisons, in the Houses of Parliament, and in a few public buildings, the importance of pure air is recognised, though scarcely with enthusiasm, and it is even admitted in behalf of our lungs and brains to be as needful in winter as in summer.

At an enormous expense, and by means of a complicated and costly machinery, attempts have been made to supply a warmair ventilation-how ineffectually may be learned by a reference to the representations of so many Members of the House of Commons in the last session of Parliament complaining that the deteriorated warm air so admitted caused irresistible feelings of lethargy and somnolence. The simple fact was that in the process of heating the pure air was deprived of a considerable portion of its oxygen with the substitution of a deadly poisonous gas. But however necessary may be a supply of pure warm air in winter in the cases of hospitals and public buildings, it will be readily conceded that it is quite as desirable in private dwellings. But what hope is there, and what inducement, for the householder to introduce such a desirable novelty when he has before him the example of the Houses of Parliament? Can the simple man. perhaps already living up to the extent of his income, be expected to sacrifice a year's rent or more in the purchase of an unsightly and cumbrous device that, after all, must prove worse than efficient? In all previous and existing systems of hot-air ventilation the pure air from outside is heated in

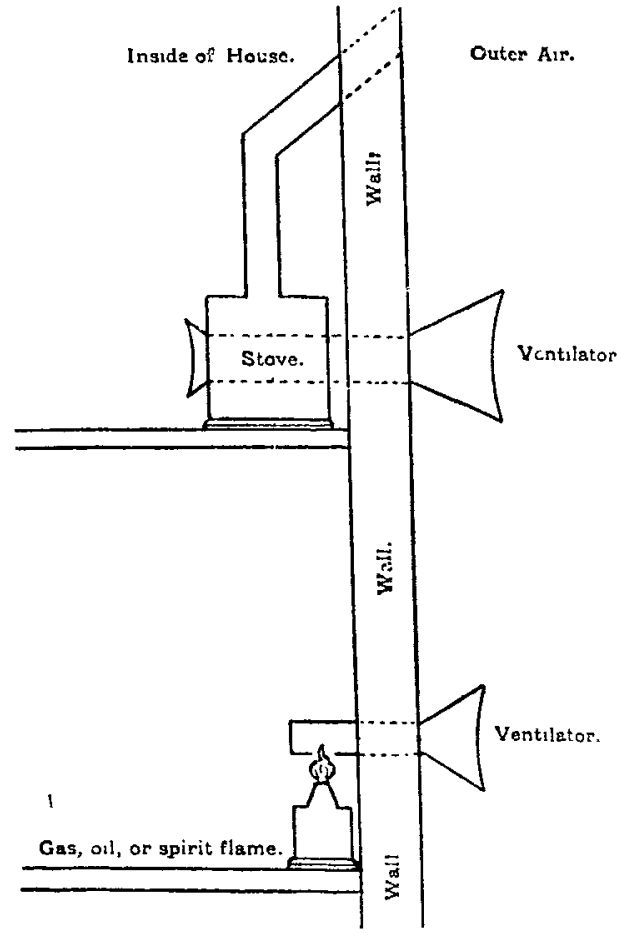

Showing simplest and cheapest form of hot-air ventilation.

For house or single room.

actual contact with the heating agent, generally an open fire of coal or charcoal, and it requires little knowledge of chemistry to understand that this cannot be done without abstraction of oxygen and the formation of carbonic acid gas.

Having these conditions in view it has occurred to me that pure air might be warmed, not thus in aperto or in the open, but in a closed tube or channel, and it next struck me that the principle has already been utilised in the case of water, as seen in the well-known geyser process. Not to trespas further on your space I will content myself with submitting a drawing that may show more clearly the idea I have endeavoured to describe. And I would particularly bes attention to the extreme simplicity, and consequent economy of such an arrangement, alike adapted to the larges building and the smallest cottage, or even to a single room. I am, Sirs, yours faithfully,

Sept. 23rd, 1905. A. C. MACLEOD, F.R.C.S. Eng., Colonel, I.M S.

\section{IS ALCOHOL EXCRETED BY THE SKIN? To the Editors of THE LANCET.}

SIRS,-Mr. D. Harris's letter in The LANCET of Sept. 30th reopens a very important question-namely, the extent to which the skin may act as an excretory organ. The matter is one which has been interesting me very considerably of late and the only conclusion to which my investigations have so far led me is that very little of a positive nature is known about it. From the aid which it is capable of giving in rapidly eliminating the uræmic poison and from the part which it plays at health resorts in gradually expelling the gouty and rheumatic toxins it is obvious that the excretory power of the skin is very considerable; that it is a function which is hygienically and therapeutically unduly neglected few would be found to deny. This neglect arises largely from the ridiculous heresy which surrounds the everyday treatment of the cutaneous surface-that, namely, which decrees that it should be continually swathed in wool or flannel. This material, being completely levoid of absorbent properties, the organ is for ever surrounded by a warm, damp, impure atmosphere, than which, as every climatologist knows, nothing is more inimical to cutaneous secretion.

Mr. Harris is probably quite right in his view that at high 
altitudes and in dry climates-under conditions, that is, which favour metabolism and cutaneous activity-alcohol, together with many other materials which in the opposite climatic conditions are either retained or forced to seek other exits, is freely excreted by the skin. And if he is it follows that flannel or woollen underwear seriously interferes with the capacity to take alcohol with impunity, a consideration which, if duly acted upon, might save many from the doleful necessity of echoing your correspondent's pathetic lament that he uselessly deprived himself of the pleasures of alcohol for a period of no less than ten years.

$$
\text { I am, Sirs, yours faithfully, }
$$

LEONARD WiLliams.

York-street, Portman-square, W., Oct. 2nd, 1905.

\section{A MINOR SIGN OF INFLUENZA. \\ To the Editors of THE LANCET.}

SiRs,-Many of the slighter forms of influenza occurring during the last quarter have exbibited. little or no rise in temperature; on the contrary, the latter may be subnormal. The individual feels ill and depressed for several days and may suffer muscular pain in different regions of the body. When he seeks medical advice the medical man probably finds nothing tangible. Now, in the majority, and particularly in those who have not complained of throat symptoms at all, there may be seen during the time, and perhaps for a fortnight subsequently, two narrow patches of congestion, symmetrical in position and usually only an inch long and less than a quarter of an inch in breadth. Each is dark-red and situated along the lateral edges of the soft palate or just encroaching upon the anterior pillars. In pale anæmic throats they are very manifest. I propose to call them "influenzal crescents." They are of assistance in the diagnosis of these indifferent states of health and are to be strictly differentiated from the influenzal throat proper. It looks as if the bacilli-laden air had struck the edges of the soft palate during its passage to the lungs. I am, Sirs, yours faithfully,

Clacton-on-Sea, Sept. 30th, 1905. WALKER OTEREND

\section{THE HONOUR OF THE MEDICAL PROFESSION. \\ To the Editors of THE LANCET.}

SIRs,-I am much your debtor, not only for the insertion of my letter of disclaimer and explanation anent the Bucci Medicine Syndicate in THE LANCET of Sept. 9th, but for the facilities for the fullest inquiry and criticism which the medium of your columns affords. Three weeks have elapsed and no response has reached me through the publicity of your journal or otherwise, and I feel that I may now fairly say with some finality, coupling this silence with the negative results which searching inquiries yielded at the outset of the prospectus, that the profession has no questions to raise in this matter nor the public any complaint to make.

I should like to make clear that in November, 1903, when the prospectus was issued, my solicitor, Mr. Sidney Newman, in whose hands I have been throughout and whose advice I have acted upon from first to last, gave the whole subject his fullest consideration and attention. Mr. Newman not only weighed the question of the disclaimer and the effect of the prospectus, which has been fully explained in my previous letter, but the propriety of applying for an injunction to restrain the firm from using my name and of entering action for damages were exhaustively investigated. As this latter process would have added some hundred pounds to my costs, he decided on financial lines to take no action, and I venture to think that subsequent events verified the astuteness of his decision, for shortly afterwards the concern went into liquidation and closed its doors and the proprietors could not be found. One of them, however, the author of the misuse of my name, recently figured in public at the Essex assizes, where in June last he was sentenced to 15 months' hard labour for frauds by means of worthless cheques at Walthamstow.

The conception of a disclaimer is not my own but in conformity with the view of the British Medical Association, which they have not till recently-July 14th last-revealed to me, and I can only repeat that to my own mind the evidence, as yet before me, amounts neither to a raison d'être of a "disclaimer," much less of an "apology" from myself. In conclusion, I trust that my explanations are sufficiently clear, adequate, and satisfactory to vindicate the course I have pursued, but $I$ am open to conviction and if any person should have any exception to take to my procedure I trust no time will be lost in making their reasons public. I am, Sirs, yours faithfully,

Alexander-square, s.W., Sept. 30th, 1905. DEnNIS VINRACE.

\section{TETANIC CONVULSIONS CAUSED BY COCAINE.}

\section{To the Editors of THE LANCET.}

SIRS,-The paper in THE LANCET of Sept. 23rd by Dr. A. E. Russell recommending subdural injections of cocaine or eucaine in cases of tetanus induces me to put on record a chse under my care in 1885 where tetanus was, in my opinion, directly caused by a hypodermic injection of the former drug.

On March 21st, 1885, at 3.30 P.M., I ligatured a large nævus on the cheek of an infant three months old. The father, who had been experimenting largely with cocaine, asked me to give a sixth of a grain hypodermically. This I did with a perfectly new and carefully cleansed syringe and a solution prepared by him. The operation was apparently painless but before the ligatures were tied tetanus set in. After finishing the operation and applying a dressing we put the child in a hot bath and gave a good dose of potassium bromide, which was repeated every three hours. Opisthotonos was well marked and spasms came on about every three minutes, the lips were livid, and the pupils were widely dilated. The spasms gradually became weaker and by 8 o'clock the child fell asleep, but the rigidity of the muscles of the neck and back lasted about 14 hours longer. It is evident that too large a dose was given but at that time the drug was considered an absolutely safe one.

It appears to me that the above case shows that extreme caution is needed in prescribing its use subdurally as a remedy for tetanus.-I am, Sirs, yours faithfully,

New Kent-road, S.E., Sept. 26th, 1905.

TERE G. WEBB, L.R.C.P. Irel.

\section{THE NOTIFICATION OF DIPHTHERIA. \\ To the Editors of THE LANCET.}

SrRs,--Whilst thanking you for the replies to my queries, perhaps you will allow me to make a few observations upon your annotation. It appears to me that you attach too much importance to the position of $\mathrm{B}$ and $\mathrm{C}$ in the matter so far as the council is concerned. The crucial point is this : Parliament in compulsorily applying the Public Health Act to every local authority, expects its provisions to be enforced under the guidance of the medical officer of health; otherwise the Act becomes a farce. The opinion of a private medical practitioner should not deter a council from performing its duty under the Act. Notification is futile if the medical officer of health's instructions are disregarded in this outrageous manner and the health of the community is consequently endangered. Laxity in the administration of the Act incites others to disobey it. I stated in my letter that the clinical signs of the disease had disappeared when $\mathbf{B}$ and $\mathbf{C}$ saw the patient ; it therefore follows that they would be absent when the second medical officer of health examined the case a week or ten days later. The defence could not maintain that the throat was for a time free from bacilli since $\mathrm{B}$ and $\mathrm{C}$ omitted to take a swab for bacteriological examination.

Oct. 2nd, 1905.

I am, Sirs, yours faithfully,

** It is essential to a prosecution of the kind suggested that there should be proof, not of the existence of a certain disease, but of the person charged being aware of its existence. The parent who was informed rightly or wrongly by $B$ and $C$ that his child had not got the disease would not be likely to be convicted of being aware of its presence, unless, as suggested in THE LANCET of Sept. 30th, p. 978, he (the parent) was proved to have concealed from $B$ and $C$ points of which obviously he ought to have informed them.-Eis. I. 